\title{
A comparison of urban planning systems between the UK and Italy: commercial development and city logistic plan
}

\author{
F. Cirianni, P. Panuccio \& C. Rindone \\ DIIES, Dipartimento di Ingegneria dell'Informazione, \\ delle Infrastrutture e dell'Energia Sostenibile, \\ Università Mediterranea di Reggio Calabria, Italy
}

\begin{abstract}
This paper focuses on planning systems in European countries, and spatial planning as a process that generates different products. The evolution of urban systems has brought on a new model of mobility and a set of negative impacts (economic, social and environmental) have increased, showing the applications for, or lack of, spatial planning. Urban spatial planning tools to pursue sustainable development vary in European countries. In this paper the structure of planning acts are examined with an eye to the tools for regulating commercial activities and relative urban freight distribution. A comparison between two different approaches, in Italy and in the UK, is presented. The two study cases are representative of the heterogeneity among Member States in spatial planning. Keywords: spatial planning, processes, commercial functions, city logistics.
\end{abstract}

\section{Introduction}

Planning can be a generic term; it involves various methods which can be applied to a variety of situations and disciplines. In the following the focus is set on spatial planning. Hereafter planning is defined as a set of processes that generates different products. A generic product-plan is defined by means of planning dimensions (space, time and study in depth). The process is characterized by interactions among subjects involved. It is possible to represent the pattern of those interactions in different planning dimensions: we may identify a dynamic for the adoption of a single plan (internal dynamic process) and a dynamic for progress among different plans (external dynamic process). 
In recent years, the European Union (EU) has attempted to introduce common standards in spatial planning. In different Member States, these attempts regard the possibility to share common objectives for spatial development. Therefore, EU provided some guidelines for national spatial development policies of the Member States. These are constituted by European Spatial Development Perspective (ESDP), developed by the Member States in co-operation with the European Commission. ESDP is a framework of planning policies to be operated across the EU, to develop principles of sustainable development and balanced urban systems [1]. Member states are adopting European principles in different ways.

The main objective of this paper is to compare European planning tools to define urban commercial functions. Doing so two aims are set: firstly, to introduce common dimensions and variables to classify planning processes and relative products; secondly, to compare the planning process between two leading European Member States to highlight the main similitudes and divergences. In particular, the two chosen study cases represent two different legislative approaches: the UK case for Common law, and the Italian case for Roman law. The selected study cases are representative for other European countries. An analysis of planning processes and relative products for urban development adopted in the two selected Member States is presented. Particular attention is paid to urban commercial functions and relative implications to freight transportation urban areas, especially in relation to economic, social and environmental implication of these activities. In section 2 dimensions and variables to classify planning processes and relative products processes are introduced. In section 3 the Italian approach and in section 4 the UK approach for urban land use planning processes and products are analyzed. In Section 5 a comparison on planning for commercial zones is presented.

\section{Planning processes and products}

The city in the last years has changed in terms of urban land expansion and increasing population. By 1990 , less than $40 \%$ of the global population lived in a city, but as of 2010, more than half of all people live in an urban area [2]. In 2006, European Environment Agency (EEA) indicated that approximately 75\% of the European population live in urban areas [3]. Cities are complex systems that include numerous functions. Urban reorganization concerns, for instance, a division of these functions, with the separation of residential from commercial areas. The emergence of out-of-town shopping malls has emphasized this separation, defining a new city model. The land market to build has failed the function to optimize the use of economic resources in order to assign the best uses in the best locations. This new growth cycle has been generated by a financial speculative process [4]. This new model of urban areas has generated a new model of mobility. Urban sprawl and resulting dispersal of home, work and leisure facilities produced an increasing transport demand [5, 6]. In 2009 the EU published the Action Plan on Urban Mobility, to take into account this transformation of urban transport systems and to render urban mobility more 
sustainable [7]. The evolution of urban systems is the process for which spatial planning has been defined. In the last decades new perspectives have been developed in planning theory. The traditional planning approaches are based on rational process theories of planning by means of an explicit and objective form of decision - making is formulated. Since the 1960s planning includes public participation and involvement. For this reason, a plurality of interests is included in planning process to reduce inequalities in the political system; these inequalities regards groups of people unorganized and unrepresented in the process. A possible approach to include these public interests is advocacy planning. Postmodern approaches to planning theory include collaborative planning that intends planning as a communicative or collaborative process. The evolution of this approach is communicative rationality planning connected to the capacity to devise, select and affect good means to clarified ends. This approach is an attempt to find a way forward for planning to justify its existence and to provide a normative basis [8, 9]. In the last years public engagement has introduced in planning process to identify and to incorporate stakeholders' concerns, needs and values in the decision-making process [10]. Planning concerns different dimensions that in common approaches comprehend: space, that is a function of the area affected by the plan, and time, that is a function of temporal period for implementing the plan and a function of temporal evolution of plan's effects. Moreover it is necessary to introduce the study-in-depth dimension, which is a function of detail in planning decisions.

In this paper the focus is on spatial planning. This typology of planning concerns decision making about spatial organisation and land use at different territorial dimensions (national, regional and local) to influence the future spatial distribution of activities. Spatial planning is an instrument for establishing longterm, sustainable frameworks for social, territorial and economic development. Spatial planning has a regulatory function and a development function for establishing directions for urban development, for preserving resources, and for establishing incentives for investment [11]. In spatial planning, in the authors' knowledge, there is not a standard form to represent planning dimensions. A possible planning dimensions classification can be formulated $[12,13]$ :

- the space dimension can be classified as: national, relative to a single state, or an aggregate of states or a portion; regional, relative to a region, from an aggregate to a part thereof; or local, relative to a town or aggregation of more than one town;

- the temporal dimension can be classified as: long-term (or strategic), referring to interventions that modify the structure of the system and that require long times and considerable financial resources; medium-term (or tactical), referring to managerial interventions relative to optimal resource allocation; short-term (or operative), referring to interventions to be made in a brief time scale;

- the study-in-depth dimension can be classified as: a directional plan which indicates objectives and strategies; a practicable plan that includes a broadening of guidelines recommended in the directional plan and specifications for single transportation subsystems (railway, roads, ...); 
a feasible plan where, for single interventions formulated within the practicable plan, technical and economic feasibility is analysed.

The planning process is affected by objectives to pursue with implementation of strategies respecting constraints. Starting from analysis of the present situation, a set of strategies can be adopted, for pursuing objectives, respecting constraints. In recent approaches, this process is based on quantitative evaluations supported by simulation models. The reference model is Land Use Transport Interaction (LUTI) models, that simulates the mutual interactions between transport mobility, spatial organisation of an area (e.g. location of residential, services activities), and land use in a urban area. LUTI models in the land use part have three main components: generation models, which provide a spatial estimation of production and consumption levels; location models, which provide a spatial distribution of production and consumption; integrated generation-location models, which jointly estimate the levels and spatial distribution of production and consumption $[14,15]$. A state-of-the-art concerning spatial economic and transport models, from national to urban scale is presented in [16]. In urban spatial planning, and specifically in the distribution of activities and then in the allocation of urban resources (financial, economic, natural, ...), commercial activities and relative urban freight transport are relevant problems to face. This mobility component has negative impacts in terms of congestion, air pollution and safety [17]. Then, an output of spatial planning is a territorial organisation of land use, assuring an equilibrium between demands for development and the need to protect the environment, and to achieve social and economic objectives [11]. In this context, a specific problem is connected to the purchasing of goods by the end user and the restocking of retail outlets, currently inserted in city logistic problems. In an urban context, simulation models that consider behavioural aspects of freight movements, mapping the behaviour of the end consumer and the retailer which generates freight movements are developed [18]. Large body of literature is present on city logistic: in a first group of papers the behavioural aspects of urban freight movements are studied ([19] and literature reported); in a second group the component relative to vehicle routing for retailer are considered $([20,21]$ and literature reported). Those models constitute the base for the simulation of goods movements at urban scale. These simulations can support definition of measures (exogenous activities) to plan urban freight transport with the goals of sustainability [22, 23], that are the core of commercial development plan and city logistic. A standard approach to represent connections from inputs and plan activities, to obtain outputs, outcomes and goals is the Logical Framework Approach ([24], and literature reported).

\section{The approach in Italy for urban land use planning}

The National Urban Planning Law of 1942, n.1150, defines the planning activity, while the specific regional laws determine procedures and implementation modalities for the governance of specific territories [25]. 
Following the social changes of the first half of the last century, this was effectively the first national planning law, and the first meaningful legislative approach to territorial regulation since the unification of Italy. Subsequently the spatial planning framework was defined by the n. 675 law in 1967, which, among other things introduces the building license [26] and the n. 10 law in 1977 that introduces a monetary cost for property development and the building concession in place of the building license [27]. In recent years the $\mathrm{n} .380$ law in 2001 introduces the building permission [28].

\section{Space dimension}

In Italy the space dimensions can be segmented for land use planning in the classes:

- national that includes National Urban Planning Law of 1942 indications;

- regional that includes special prescription plans, directives and address for the subordinate levels (Regional Territorial Plan);

- local that includes intermediate plans for coordination and provincial guidelines for the bottom layer and municipal plans of regulation and implementation.

In the following local dimension is focused.

The local plan, having implemented the general guidelines and constraints binding by higher-level planning instruments, becomes the instrument to measure urban planning performances. It can be said that the implementation of planning decisions is obtained through the normal planning tool at the local level [29]. The local plan is regulated under the law of the regional reference. The theory generally ordered by the prevalence of the Italian regions, prefigures a local plan composed of a structural part, indicative of permanent characters and slow modification, and a part that refers to the feasibility of the plan forecasts in the medium-short period.

Municipal plans are structured sharing balance between constraints, objectives, and activities. The integration of constraints, objectives and activities made the tool: evaluation and selection of decision-making objectives and sustainable actions, graded by means of a system of constraints calibrated for intervals of compatibility to the uses, functions, usability, possibility to do. In practice, common planning approaches are limited on a passive reception of law' constraints.

\section{Temporal dimension}

The temporal dimension distinguishes at least three classes: long term, that comprehends regional, intermediate and municipal plans, which set the framework and the standards; medium term that comprehends the part of a plan with a definite expiration (for instance municipal plans including administrative constraints); short-term plan, defining to implementation and physical plans, for instance the operative plans. The provisions given in the relevant plans should be fulfilled within a given time horizon, but matter-of-factly the system of constraints imposed by higher-level land use plans, consisting of absolute constraints, remains unchanged until the subsequent amendment of planning. These constraints are imposed by national laws and are perceived ope legis by 
instruments of any territorial scale. For instance, the following constraints are absolute: landscape, protected areas, hydrogeological, seismic risk and more.

The decisions laid down in the urban planning at the local level remain in force until a variation or new plan is approved, but can be in derogation if there is a deliberative institution with hierarchal higher-level of powers. In the last twenty years, the country has been transformed by the realization of financed projects, as for the European public access projects, often not covered by regulatory instruments of planning. Subsidized development for the design and execution of works, have often bypassed the planning instrument, depriving it of the chance to foresee and regulate the organizational structure and the sustainable use of the territory.

\section{Study in depth dimension}

The study in depth dimension distinguishes at least three classes: director that includes structural indications to feed planning process, at national, regional and urban scale; executable that includes plans translating director indications in detailed plan for instance commercial plan, urban green plan, colour plan, restoring plan, urban mobility plan (PUM), urban traffic plan (PUT); feasible that includes plans with a preparatory function for building design, for instance lotting plans.

The main regulatory tools of Italian planning process are listed in Table 1, which is related to the three given dimensions (space, time, study-in-depth).

\section{The approach in UK for urban land use planning}

Modern town and country planning in Great Britain emerges, with the Town and Country Planning Act 1947 (T\&C planning Act) [30].

The process that led to this was a consequence of the social revolution of the previous century, following the industrial revolution and the subsequent urbanization. Urbanization led in industrial cities to pollution and slums, and as a vaster phenomenon the side effect brought on by political and social changes was unregulated development, leading to patterns of the like of urban sprawl, and ribbon development.

The T\&C planning Act reorganized the whole planning system, it cut the number of the planning authorities, from the 1,400 existing to 145 , and introduced the requirement for planning authorities to prepare a comprehensive development plan. It introduced a concept novel to the existing Common Law, which put the right to develop land in the hands of the Public Authority (interesting comparisons can come from the parallel with the debate on the Ius Edificandi of the Roman Law).

Space dimension

In UK the space dimensions for land use planning are [31, 32]:

- national level: the UK government publishes the National Planning Policy Framework (NPP), that replaced Planning Policy Statements (PPS) and that is used to support national and local planning decisions; national significant infrastructure projects are determined by the decision-making framework set out in national policy statements, which are part of the overall framework of 
planning policy. NPP indicates the things Local Plans must consider, including policies on economic growth, housing, transport, community facilities and climate change.

- regional level: in the areas of England outside of London there is no regional strategic plan. The Localism Act 2011 is abolishing this regional tier of planning. Decision-making powers on housing and planning are transferred to local councils. In areas outside of Greater London, strategic plan making will be undertaken at a local level where Local Planning Authorities will be expected to address strategic issues through the new 'duty to co-operate' set out in the Localism Act 2011;

- local level, how specified by T\&C planning Act that introduces for all developments (with a few exclusions only):

1) the requirement of planning permission from the local authority;

2) the development charge to capture the planning gain (which was abolished by the Town and Country Planning act of 1954);

3) the requirement on local authorities to develop Local Plans (LP) or Unitary Development Plans (UDP).

In the following local dimension is focused.

In the LP local authority decides the strategic priorities for the area (for instance housing and economic development, infrastructure for transport, minerals, waste, energy, telecoms, water supply and water quality, health, security, community, infrastructure and other local facilities). These strategic priorities are contained in the Local Development Documents [32].

At the heart of the planning system is a presumption in favour of sustainable development, which should be seen as a golden thread running through both plan making and decision taking. Local planning authorities should plan positively for new development, and approve all individual proposals wherever possible.

LP and UDP outline where development is permitted, and the nature and kind of it, and defining on maps different areas. At a broader territorial scale, usually the Counties, the Structure Plans set the broad targets for the wider area.

A various number on minor and major interactions were added during the years, and they were consolidated in the Town and Country Planning Act 1990 (TCPA 1990) [33]. Among the major amendments introduced there is the planning obligation agreements, under which the developer is subject to detailed arrangements and restrictions beyond those that a planning condition could impose, or by which he makes agreed financial contributions beyond the immediate building works to offset development effects on the local community.

The Planning and Compulsory Purchase Act 2004 made substantial changes to the English Development Plan system [34]. Since the adoption of the 2004 Act there are no longer Structure Plans and Local Plans. The structure plans are replaced as the strategic planning document by the Regional Spatial Strategy (RSS), which is produced by Regional Assemblies in England [35]. Local Plans have been set aside in favour of Local Development Frameworks (LDFs), which are made up a number of Local Development Documents (LDDs) and Supplementary Planning Documents (SPDs). Local Authorities are also now required to produce Local Development Schemes (LDS) - which outline the 
work the LDDs/SPDs they intend to produce over a three-year period, and Statements of Community Involvement (SCI), which outline how the Council will involve the local community [36]. All LDDs and SPDs also have to be accompanied by a Sustainability Appraisal (SA) and a Strategic Environmental Assessment (SEA). The SEA is a requirement under European Union laws. Planning Policy Guidance Notes are also being gradually replaced by Planning Policy Statements.

Table 1: $\quad$ The Italy and UK planning products classification.

\begin{tabular}{|c|c|c|c|}
\hline Dimensions & Classes & Italy & UK \\
\hline \multirow{3}{*}{$\begin{array}{l}\tilde{\tilde{n}} \\
\text { कि }\end{array}$} & local & $\begin{array}{l}\text { Intermediate plan } \\
\text { Municipal Plan }\end{array}$ & LDS (Local Development Schemes) \\
\hline & regional & Regional Territorial Plan & RSS (Regional Spatial Strategy) \\
\hline & national & $\begin{array}{l}\text { National Urban Planning } \\
\text { Law of } 1942\end{array}$ & $\begin{array}{l}\text { The Planning and Compulsory } \\
\text { Purchase Act } 2004 \\
\text { National Planning Policy Framework }\end{array}$ \\
\hline \multirow{3}{*}{ 音 } & $\begin{array}{l}\text { short } \\
\text { term }\end{array}$ & Operative Plan & $\begin{array}{l}\text { Supplementary Planning Documents } \\
\text { (SPDs) }\end{array}$ \\
\hline & $\begin{array}{l}\text { medium } \\
\text { term }\end{array}$ & $\begin{array}{l}\text { Municipal plan (for } \\
\text { administrative } \\
\text { constraints) }\end{array}$ & $\begin{array}{l}\text { Local Development Documents } \\
\text { (LDDs) }\end{array}$ \\
\hline & $\begin{array}{l}\text { long } \\
\text { term }\end{array}$ & $\begin{array}{l}\text { Regional Territorial Plan } \\
\text { Intermediate Plan } \\
\text { Municipal Plan }\end{array}$ & $\begin{array}{l}\text { RSS (Regional Spatial Strategy) } \\
\text { Local Development Frameworks } \\
\text { (LDFs) } \\
\text { National Planning Policy Framework }\end{array}$ \\
\hline \multirow{3}{*}{ 总葶 } & feasibility & Lotting plans & \\
\hline & executable & $\begin{array}{l}\text { Execution plans; detailed } \\
\text { plan; commercial plan; } \\
\text { urban green plan; colour } \\
\text { plan; restoring plan } \\
\end{array}$ & \\
\hline & director & $\begin{array}{l}\text { Municipal Plan } \\
\text { Intermediate plan } \\
\text { Regional Territorial Plan }\end{array}$ & $\begin{array}{l}\text { National Planning Policy Framework } \\
\text { Local Development Frameworks } \\
\text { (LDFs) }\end{array}$ \\
\hline
\end{tabular}

\section{Commercial plans}

\subsection{The Italy approach}

In the Italian system the commercial municipal plan is laid out to support the plan for the government of the region and is carried out in accordance with the guidelines from the higher-level Regional and Provincial tools. The choices we operate according to the conservation of primary resources, protection of not built spaces of landscape and environmental value, and integration of commercial activities with the local productive system; rational organization of mobility warranty neighbourhood businesses as an essential local service.

A case study is analysed, the commercial plan of the town of Viganò, in Lombardy region. The plan descends from the previsions of the regional law of Lombardy [37], coherently with the indications set by the national law, n. 114/1998 which set the reform of the regulation for the commercial sector [38]. 
Accordingly, the local plans set: the areas for the commercial development, for medium to large retail parks; the constraints, according to environmental, cultural and landscape; planning standards for spatial parameters, as roads parking and services. The principal aims are to define the distribution network, integrating it with mobility, traffic and environmental factors, and the safeguard and requalification of city centres. In fact a large part of commercial plans considers city logistic aspects and produces related indications. To analyse quantitative effects some hypotheses about end consumers and the retailers behaviour have to introduce. To differentiate the two purchasing processes, attraction models are developed to represent the process of the end consumer, and acquisition models to represent retailer process.

\subsection{The UK approach}

In the UK there are not special laws governing new retail development, but retail developments are promoted through the land-use planning system.

UK government aims to achieve sustainable development. Therefore, retail developments are concentrated in existing centres to sustain and enhance them. Out-of-centre retail developments are restricted to reduce reliance on private cars, encourage the use of public transport and walking and cycling, and ensure that everyone has access to a range of retail facilities. Effects of these policies can be simulated by means of specific quantitative models. Local planning authorities balance the hierarchy of centres to ensure that they are not overly dominated by the largest ones. Local planning authorities ensure that the scale of development matches the role and function of each centre within the wider hierarchy.

National Planning Policy Framework in 2012 highlights the promotion of competitive town centres that provide customer choice and a diverse retail offer and which reflect the individuality of town centres.

Local planning authorities should use this evidence base to assess the needs for land or floorspace for economic development, including both the quantitative and qualitative needs for all foreseeable types of economic activity over the plan period, including for retail and leisure development [39].

In the UK commercial developments are defined in the Unitary Development plan, or proposed by developers, by the use of the process known as planning obligation agreements or more commonly Section 106 agreements.

The concept of agreements, under which the developer is subject to detailed arrangements and restrictions beyond those that a planning condition could impose, or by which he makes agreed financial contributions beyond the immediate building works to offset development effects on the local community.

Some examples of policies for the promotion of development for trade and commercial schemes have been seen in the enterprise zones and the urban development corporation's policies [40]. 


\section{Acknowledgement}

This work has been partially funded by the Italian Ministry for Education, University and Research within the project PRIN2008 grant No. prot. 2008YEPPM3_002.

\section{References}

[1] EC, European Commission, ESDP European Spatial Development Perspective Towards Balanced and Sustainable Development of the Territory of the European Union, 1999, http://ec.europa.eu/ regional_policy/sources/docoffic/official/reports/pdf/sum_en.pdf (last access February 2013).

[2] World Health Organisation, Urban population growth, 2013, http://www.who.int/gho/urban_health/situation_trends/urban_population_gr owth_text/en/index.html (last access February 2013).

[3] EEA, European Environment Agency, Urban sprawl in Europe. The ignored challenge, ISSN 1725-9177, Office for Official Publications of the European Communities, Luxembourg, 2006, www.eea.europa.eu (last access February 2013).

[4] Miralles i Garcia, J.L., Díaz Aguirre, S., Altur Grau, V.J., Environmental impact on the Mediterranean Spanish coast produced by the latest process of urban developments, WIT Transactions on Ecology and the Environment 155, pp. 379-389, M. Pacetti, G. Passerini, C.A. Brebbia, G. Latini (Eds), WIT Press, Southampton, 2011.

[5] EC, European Commission. Green Paper. Towards a new culture for urban mobility, 2007, http://europa.eu/legislation_summaries/transport/bodies_ objectives/124484_en.htm (last access February 2013).

[6] Caglioni, M., Pelizzoni, M., Rabino, G.A., Urban sprawl: A case study for project gigalopolis using SLEUTH model, Lecture Notes in Computer Science (including subseries Lecture Notes in Artificial Intelligence and Lecture Notes in Bioinformatics) 4173 LNCS, pp. 436-445, Springer Verlag, ISSN: 0302-9743 2006.

[7] EC, European Commission, Action Plan on Urban Mobility - State of Play, 2012, http://ec.europa.eu/transport/themes/urban/urban_mobility/doc/apum _state_of_play.pdf (last access February 2013).

[8] Allmendinger P., Planning Theory, 2nd edition, Palgrave and Macmilian, 2002.

[9] Las Casas G., Sansone A., Una cultura della pianificazione in un approccio rinnovato alla razionalitá nel piano, in Deplano G. Politiche e strumenti per il recupero urbano, Edicom Edizioni, Monfalcone (GO), ISBN: 978-8886729-53-5, 2004.

[10] OECD, Organisation for Economic Co-operation and Development. Focus on Citizens: Public Engagement for Better Policy and Services. ISBN 9789264048867, 2009. 
[11] UNECE, United Nations Economic Commission for Europe, Spatial planning. Key Instrument for Development and Effective Governance with Special Reference to Countries in Transition, 2008 http://www.unece.org /fileadmin/DAM/hlm/documents/Publications/spatial_planning.e.pdf (last access February 2013).

[12] de Luca M., Manuale di pianificazione dei trasporti, CNR - Progetto Finalizzato Trasporti 2, Franco Angeli Ed., Milan, 2000.

[13] Russo F. \& Rindone C., Safety of users in road evacuation: planning internal processes and guidelines. WIT Transactions on the Built Environment 96, pp. 825-834, Brebbia C.A. (ed.), WIT Press, Southampton, 2007.

[14] Lowry, I.S., A Model of Metropolis. Report RM 4125-RC. Rand, Santa Monica, 1964.

[15] Ibeas, Á., Cordera, R., Dell’Olio, L., Coppola, P., Modelling the spatial interactions between workplace and residential location, Transportation Research Part A: Policy and Practice 49, pp. 110-122, Elsevier, 2013.

[16] Russo F. \& Musolino G., A unifying modelling framework to simulate the Spatial Economic Transport Interaction process at urban and national scales. Journal of Transport Geography 24, Elsevier, pp. 189-197, 2012.

[17] Cirianni F. \& Leonardi G., Environmental modeling for traffic noise in urban area, American Journal of Environmental Sciences 8 (4), pp. 345351, Science Publications, ISSN: 1553-345X, 2012.

[18] Lapucci, A., Lombardo, S., Petri, M., Rotonda, M., A participative multi agent system for urban sustainable mobility, Studies in Computational Intelligence 176 , pp. 255-279, Springer Verlag, ISSN: 1860-949X, 2009.

[19] Russo F., Modeling behavioral aspects of urban freight movements, in: Freight Transport Modeling, Eds Ben-Akiva, M. E., Meersman, H. \& Van De Voorde, Emerald Group Publishing Limited, ISBN: 9781781902851, 2013.

[20] Polimeni A., Russo F. \& Vitetta A., Demand and routing models for urban goods movement simulation. European Transport - Trasporti Europei, 46, pp. 3-23, ISTIEE, Trieste, Italy, 2010.

[21] Polimeni A. \& Vitetta A., Optimising waiting at nodes in time-dependent networks: cost functions and applications. Journal of Optimization Theory and Applications, 156(3), pp. 805-818, Springer, 2013.

[22] Russo F. \& Comi A., City characteristics and urban goods movements: A way to environmental transportation system in a sustainable city, Procedia - Social and Behavioral Sciences 39pp. 61 - 73, Elsevier, 2012.

[23] Russo F. \& Comi A., Measures for Sustainable Freight Transportation at Urban Scale: Expected Goals and Tested Results in Europe Journal of urban planning and development (C) American Society of Civil Engineers, ASCE, DOI: 10.1061/(ASCE)UP.1943-5444.0000052, 2011.

[24] Russo, F., Rindone, C., The planning process and logical framework approach in road evacuation: A coherent vision, WIT Transactions on the Built Environment 117, pp. 415-425, Brebbia C.A. (ed.), WIT Press, Southampton, 2011. 
[25] Italian Government, Law 17 August 1942, n. 1150. Legge Urbanistica, 1942, http://www.bosettiegatti.com/ info/norme/ statali/ 1942_1150.htm (last access, February 2013).

[26] Italian Government, Law 6 August 1967, n. 675. Modifiche ed integrazioni alla legge urbanistica 17 agosto 1942, n. 1150, http://www.normattiva.it/ uri-res/ N2Ls?urn:nir:stato: legge:1967-08-06;765! vig (last access, February 2013).

[27] Italian Government, Law 30 January 1977, n. 10. Norme per la edificabilità dei suoli, 1977 http:// www.normattiva.it /uri-res/ N2Ls?urn:nir: stato: legge: 1977 - 01 - 28;10 @ originale (last access February 2013).

[28] Italian Government, DPR 6 June 2001, n. 380. Testo unico delle disposizioni legislative e regolamentari in materia edilizia. http://www.parlamento.it/parlam/leggi/deleghe/01378dla.htm (last access February 2013).

[29] La Greca P., From urban design to regional policies: a new role for planners in Italy; in Martinico F. (a cura di) Ricerca didattica e prassi urbanistica nelle cittá del mediterraneo Ed. Gangemi, Rome Italy, ISBN 978-88-4922220-3, (2011).

[30] UK Parliament, Acts of Parliament of the United Kingdom, 10\&11 George VI, c.51, 1947.

[31] UK DCLG, UK Department for Communities and Local Government, 2011, www.communities.gov.uk/publications/planningandbuilding/nppf (last access February 2013).

[32] Royal Town Planning Institute, Handy Guide to Planning, 2012, http://www.rtpi.org.uk/media/1454776/planning_handy_guide_2012_5_fin al.pdf (last access February 2013).

[33] UK Government, Town and Country Planning Act 1990, http://www.legislation.gov.uk/ukpga/1990/8/contents (last access February 2013).

[34] UK Government, Planning and Compulsory Purchase Act 2004, www.legislation.gov.uk/ukpga/2004/5/contents, (last access February 2013).

[35] UK Government, Localism Act 2011, http:// www. legislation .gov. uk / ukpga / 2011/ 20/ enacted (last access February 2013).

[36] Newton R. and Planning Aid England, The handy guide to planning, Second edition, Urban Forum, ISBN 978-0-9569096-1-9, 2012.

[37] Lombardia Region. Regional Law 11 March 2005, n. 12. Legge per il governo del territorio, http:// www.territorio. regione.lombardia.it/ shared/ ccurl/ 660/685/LR_12_2005_aggiornata_al_10-05-2012.pdf (last access February 2013).

[38] Italian Government. Law 31 March 1998, n. 114. Riforma della disciplina relativa al settore del commercio, a norma dell'articolo 4, comma 4, della legge 15 marzo 1997, n. 59. http:/www.parlamento.it/ parlam/leggi/ deleghe/ 98114dl.htm (last access February 2013).

[39] UK Government, National Planning Policy Framework, Department for Communities and Local Government, ISBN: 978-1-4098-3413-7, 2012 
https://www.gov.uk/government/uploads/system/uploads/attachment_data/f ile/6077/2116950.pdf (last access February 2013).

[40] Hall P. G., Tewdwr-Jones M., Urban and Regional Planning, Routledge, 2011. 